\title{
The role of Parliament in promoting active citizenship in relation to the Grade 11 Life Orientation in the South African curriculum
}

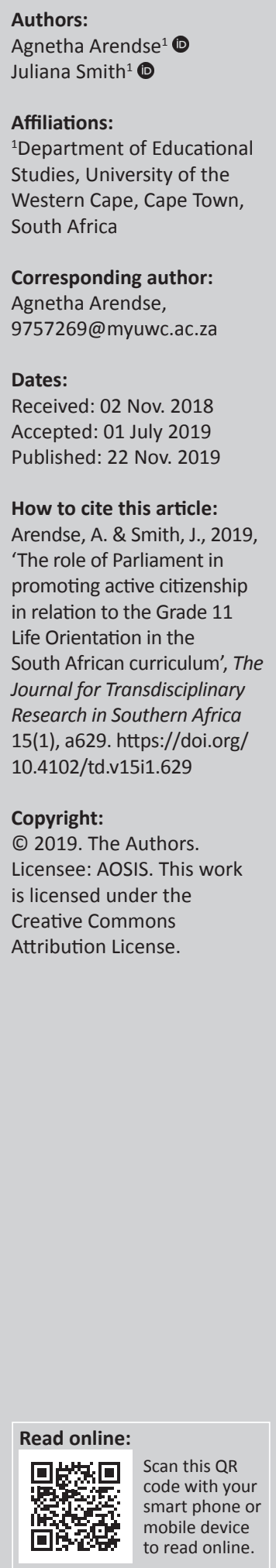

The Parliament of the Republic of South Africa plays a pivotal role in promoting active citizenship to ensure the deepening of democracy. This article, as based on the study by Arendse, explored the extent to which Parliament as a key participatory institution promotes active citizenship in relation to the Grade 11 Life Orientation (LO) curriculum in South Africa. A qualitative, interpretive approach was employed. However, data were gathered through the crystallisation approach using different methods of gathering data such as document study, questionnaires and focus group interviews, which involved 461 Grade 12 LO learners who had completed the Grade 11 LO curriculum during 2012 and seven LO educators. The findings suggest that there is: (1) lack of exposure, knowledge and understanding about Parliament; (2) lack of public education programmes and initiatives about Parliament; and (3) limited information about Parliament in the LO curriculum.

Keywords: Active citizenship; citizenship education; Life Orientation; Parliament of the Republic of South Africa; public participation.

\section{Introduction}

This article focuses on the extent to which Parliament as a key participatory institution promotes active citizenship in relation to the Life Orientation (LO) curriculum. South Africa has undergone radical transformation from an apartheid system to a democracy, and new policies and mechanisms were put in place to address the inequalities of the past (Smith \& Arendse 2016). Since 1994, all sectors embarked on this transition with its aim of instilling a culture of democracy in South Africa. A system of co-operative governance emerged which includes the three arms of State, namely Legislature (Parliament), Executive (Government) and the Judiciary (Courts). As one of the arms of State, Parliament is regarded as one of the key participatory institutions to promote active citizenship in a democracy.

In response to radical transformation from apartheid to democracy, the Education Department initiated curriculum changes to embrace the notion of a democratic South Africa. The curriculum is thus based on principles that were inspired by the Constitution, including transformation, human rights, inclusivity and social justice. In essence, the curriculum aims to equip learners with the necessary knowledge, values and skills in order to promote active citizenship in a democracy (Department of Basic Education [DBE] 2010:4).

Furthermore, Parliament initiated various mechanisms to provide the public with an opportunity to participate actively in its processes such as law-making and oversight (Parliament of the Republic of South Africa [RSA] 2010). In order to participate optimally and meaningfully in democratic processes, it is thus essential to be informed and educated about the relevant processes. However, the study revealed that there is a lack of education programmes and initiatives about Parliament and its processes. This implies that the public are not well informed enough to make meaningful contributions to democratic processes. Furthermore, the results confirm the reason for apathy about Parliament amongst learners and educators.

Since 1994, South Africa embarked on a democracy. Democracy has many meanings to different people, which implies that its definition is broad and contextual. For example, democracy is about freedom, respect, liberties and having your voice heard (Honohan 2005; Sen 1999). There are different types of democracies, namely direct, representative and participatory democracy. In the South African context, a representative participatory democracy approach was employed. In a representative democracy, the elected representatives solely represent the views of the 
people (Calland 1999), whilst in a participatory democracy the public is actively involved in the decision-making of the government (De Villiers 2001). It therefore becomes imperative for citizens to be informed and educated about democratic processes to participate optimally in participatory structures. Education plays a vital role in promoting active citizenship, yet many educators lack substantial knowledge and understanding about a key democratic institution such as Parliament.

There have been various education initiatives aiming to promote active citizenship. For example, the Curriculum and Assessment Policy Statement (CAPS) is based on principles such as social transformation, human rights, inclusivity and social justice, which were built on the values inspired by the Constitution (DBE 2011b:4). More specifically, the LO curriculum addresses skills; knowledge; and values about the self, the environment, responsible citizenship; a healthy and productive life; social engagement; recreation and physical activity, careers and career choices; with an emphasis on the importance of the application of skills and values in real-life situations; and participation in physical activity, in community organisations and initiatives (DBE 2010:9).

Furthermore, Parliament, as one of the key participatory institutions, has many public participation initiatives, with the intention of increasing active citizenship in a democratic South Africa. These initiatives include annual events such as Taking Parliament to the People, Women's Parliament, Youth Parliament and the State of the Nation Address (Parliament of RSA 2010). In addition, Parliament has structured processes for active participation including making submissions, petitions, lobbying, representation and contacting a Member of Parliament (MP). Sections 56 (d) and 69 (d) of the South African Constitution make provision for public participation by enabling the National Assembly and the National Council of Provinces to receive petitions and submissions from individuals or institutions (Constitution of the Republic of South Africa [RSA] 1996).

The Department of Education plays a pivotal role in educating learners about active participation in democratic processes with the intention to create learners who will become active and responsible citizens. However, this article shows that Grade 12 learners were ill-informed about the aspects relating to active citizenship, which may be indicative of a mismatch between the intention of the curriculum and the reality of its implementation.

In both instances, there are intentions to equip and empower the public to become active citizens. However, the lack of knowledge and understanding of democratic processes implies that there is a disjuncture between intention and implementation.

\section{Theoretical and conceptual framework \\ Theoretical framework}

The study by Arendse was guided by the teachings of Paulo Freire, a critical theorist and education philosopher who argues strongly for political education (McCowan 2006). He believes that individuals are not naturally ready to participate in politics but have to be educated in democratic politics (Torres \& Teodoro 2007). Freire's work revolves around a concept called 'praxis', which is about analysis, discussion and action to change a situation in order to create a new situation and for true learning to occur (Harmon 1975). In other words, 'praxis' is about an integration of reflection and action, practice and theory, critical thinking and doing.

Critical theorists, including Paulo Freire not only describe a situation from a specific point of view but rather aim to change the situation as critical theory tends to create a sense of awareness about social issues, and it has the potential to critique and initiate transformation through action (Ewert 1991; Wright 2007). Critical thinking, action and consciousness are very important and imperative to the democratic process as they promote dialogue, which is the key to democracies. Freire firmly believes that schools are agents of change and should be responsible for educating learners about the aspects of democracy and for teaching learners how to become critical thinkers in society (Freire 1971). It can thus be said that education for active citizenship including democracy and human rights should be about critical thinking, self-reflection and emancipation through education and empowerment (Arendse 2014).

\section{Conceptual framework}

The conceptual framework that formed part of the literature, together with the theoretical framework that underpinned the study, guided the study (Vaughn 2008). It provided an 'understanding of active citizenship', 'education for active citizenship', 'Parliament and active citizenship' and 'Life Orientation curriculum and active citizenship'. It discussed Parliament and the South African curriculum in relation to active citizenship in a democracy.

\section{Understanding active citizenship}

Active citizenship has different meanings in diverse contexts (European Commission 2007). For example, in Germany the focus is on political education, whilst in France it is on civic knowledge, and in England, it is on citizenship education. Countries such as Estonia, Sweden and Portugal emphasise social education, values-based education or personal and social development (Nelson \& Kerr 2005:10). Active citizenship not only allows citizens to access rights and obligations but inherently it entails education, practice and involvement in democratic processes (European Commission 2007). Citizens should thus understand that they have the power to influence decision-making in political processes through participation in processes such as voting, petitions and joining political parties and volunteer organisations. Being an active citizen can result in social transformation and the eradication of inequality (McCloskey 2017), which equips learners with the skills, values, knowledge and understanding needed to analyse problems critically and devise actions to address them. 
Active citizenship develops an awareness of interdependence, an attitude of civic self-restraint and openness to deliberative engagement. Active citizenship, regardless of the various contexts, revolves around the notion of action, of involvement, education and practice (European Commission 2007). Active citizenship involves values, knowledge, skills, attitude and context. An active citizen can therefore be defined as a citizen who strives to build a better society democratically by being respectful of the opinions of others, one who is committed and who openly challenges the status quo for the good of all.

Active citizenry and social activism are necessary for democracy and development to flourish (National Development Plan 2030 [NDP] 2012). This implies that the State cannot merely act on behalf of the people through representation only; it must act with the people, working together with other institutions to provide opportunities for the advancement of all communities. The government therefore needs to provide the channels for ordinary citizens to influence decision-making and resource allocation for the future of their communities, towns and cities.

\section{Education for citizenship}

Citizens need to be empowered to become actively involved in democratic processes. A means of empowerment could be through various civic education programmes. It is noteworthy that the nature of civic education programmes relies heavily on the context within which they may be applied. For example, citizenship education programmes may include aspects such as status, identity, civic virtue and agency, or they may address various perspectives on citizenship such as liberal, communitarian and civic republican perspectives. Regardless of the context, however, it is argued that citizenship education programmes should prepare learners to become active citizens by ensuring that they acquire the necessary skills and attitudes to contribute to the development and well-being of the society in which they live (European Commission 2012).

The value of education for citizenship is embedded in the notion that every society ideally needs citizens who positively contribute to the well-being and existence of its nation. Furthermore, nurturing active citizenship enhances the growth of a democratic nation, promoting citizen participation in democratic processes. Education allows citizens to become aware of their environment and the social and economic options available to them (Kuye 2007).

It is also vital for citizens to know and understand their rights as stipulated in the Constitution. The Bill of Rights in Chapter 2 of the Constitution (Constitution of RSA 1996) highlights all the rights and responsibilities that all citizens can exercise. However, the study by Arendse suggests that the public is not well informed about the rights that they can access. There is a need, therefore, for an education in citizenship, which ideally entails aspects relating to democracy, human rights, inclusivity and public participation.

\section{Parliament and active citizenship}

Public participation and involvement in participatory processes is crucial for the success of a democracy (Institute for Democracy Association in South Africa [IDASA] 2012). There are different ways in which the public can actively engage with Parliament to influence decision-making processes (Parliament of RSA 2010). Parliament promotes public participation in its processes through public education activities or initiatives (Parliamentary Communication Services [PCS] 2007). A Public Education Office was thus established to provide information and ongoing curriculum development and education about the processes, roles and structures of Parliament to communities; to conduct a visitorsto-Parliament programme; and to facilitate meaningful interface sessions between MPs for visitors (PCS 2007).

South Africa has a multi-party democracy that provides citizens aged 18 years and older the opportunity to vote for a political party of their choice to represent them in decision-making processes in Parliament. The number of seats a political party gets, in proportion to the number of votes, is called proportional representation (Parliament of RSA 2010). Proportional representation means that a political party obtains a specific number of seats in Parliament according to the number of votes it receives during elections. Political parties have constituencies within the communities where MPs become a direct link between the community and government to ensure government by the people under the Constitution. Citizens have a right to raise concerns at their constituencies and the MPs in turn raise these issues on behalf of the community in Parliament for further debates and discussions. However, in theory, the public can participate in Parliament in this one way, yet in practice, it is apparent that the constituencies are not very visible, and people may not know where their constituencies are situated.

The facilitation of public participation and involvement in its processes thus remain central to the mandate of Parliament within the context of a participatory and representative democracy. Sections 59 and 72 of the Constitution thus compel Parliament to facilitate public involvement in its legislative and other processes (Constitution of RSA 1996).

\section{Life Orientation curriculum and active citizenship}

The LO curriculum is regarded as the main vehicle for the development of knowledge, values and skills about active citizenship. The curriculum is based on principles including transformation, social justice, human rights and inclusivity. The LO curriculum addresses skills relating to responsible citizenship including the application of these skills in real-life situations (DBE 2011b). The inclusion of these skills suggests that the national curriculum promotes active citizenship in a democracy. It is thus evident in the policy statements that the vision expressed in the curriculum is to equip learners with the necessary knowledge and skills to become active citizens making meaningful contributions to society (DBE 2010).

Human rights concepts have thus been infused into subjects such as Life Orientation with a focus on responsible citizenship. 
Human rights and citizenship education have become integral to the aims of the LO curriculum (Keet et al. 2001). However, many challenges have emerged with the introduction of citizenship education in the LO curriculum, especially as it relates to integration across subjects and lack of resources. Integration across disciplines may minimise the relevant content knowledge (Department of Education [DoE] 1997; Gillespie 2002; Rooth \& Schlebusch 2000), which implies that it may lose the essence of the concept or topic.

\section{Methods}

This study was conducted within a qualitative research paradigm with the aim of obtaining an in-depth understanding of the extent to which Parliament promotes active citizenship in a democracy.

\section{Research design: Case study}

A qualitative case study was conducted to explore the extent to which learners are prepared for active citizenship in relation to Parliament and the LO curriculum in context, using a variety of data sources (Baxter \& Jack 2008). An interpretivist approach was conducted as it considered the LO learners' and educators' experiences and reality (Terre Blanche \& Durrheim 2006), and it sought to capture their everyday lives in order to interpret the meaning and get a deeper understanding of their perceptions about democratic structures (Henning, Van Rensburg \& Smit 2004). Five schools were selected as a case from the Metro South Education District in the Western Cape, which made it possible to explore the perceptions and understanding of Grade 12 learners and LO educators about Parliament as a democratic structure which generated rich descriptions where many views and numerous quotations from different voices are provided.

\section{Data collection methods and instruments}

Questionnaires were administered to establish the level of both learners and educators' knowledge about Parliament and active citizenship as well as their understanding of the concept 'public participation'. This informed the interview schedule for follow-up focus group interviews. Focus group interviews with a sample of 40 Grade 12 learners, who completed the Grade 11 LO curriculum in 2012 and six LO educators, were conducted. The focus group interviews were conducted to provide an in-depth understanding of participants' perceptions about relevant concepts. They also sought to provide a rich description of the phenomenon (Schostak 2002).

In addition to questionnaires and focus group interviews, document study was conducted. Document study can be described as an examination of written materials that contain information about the topic under investigation (Strydom \& Delport 2005). Various parliamentary documents were studied such as business plans, policy imperatives and information publications, as well as well as curriculum policy documents of the DoE. The data were crystallised as information was collected from different sources and by using different instruments, which thus validated the responses in relation to the research question (Babbie \& Mouton 2001).

\section{Procedure for data collection}

Ethical clearance was obtained from the University of the Western Cape Senate Research Ethics Committee. Permission to conduct research was also granted by the Western Cape Education Department (WCED), Metro South Education District (MSED) office and the schools. Informed consent from LO educators and consent from the parents of Grade 12 learners was obtained for participation in the administration of the questionnaires as well as the focus group interviews. Schools were representative in terms of race, age, socioeconomic status and levels of resources. Ethical principles were adhered to whereby participants were assured of privacy, confidentiality and anonymity, and participants had the right to withdraw at any stage of the research process.

\section{Data analysis}

As this study referred to in this article explored the knowledge about and understanding of active citizenship on the part of Grade 12 learners, and explored various concepts relating to active citizenship in a democracy, thematic and document analyses were used (Coolican 1999). Data from the questionnaires were captured and coded on an Excel spreadsheet only, and it was not statistically analysed through statistical methods and techniques.

Document analysis included an examination of various policy and institutional texts from the national curriculum and Parliament, with the aim of searching for connections with the research questions as well as examining patterns and inconsistencies that may have emerged in this regard.

Focus group interviews were conducted with Grade 12 learners and LO educators, from which various categories and themes emerged, and these themes were categorised for in-depth discussion.

\section{Research participants and context}

The participants included 461 Grade 12 learners and seven LO educators from five schools in MSED in the WCED. A purposive sampling method was used which ensured that the participants selected were information-rich relating to the purpose of the study (Gall, Borg \& Gall 1996). In total, 757 Grade 12 learners were invited to participate, 461 learners of whom completed and returned the questionnaire. In addition, 40 learners participated in the focus group interviews. Seven educators were invited to participate, four educators of whom returned the questionnaire and six of whom participated in the focus group interviews.

\section{Ethical consideration}

All participants were treated with respect and sensitivity. As noted earlier before conducting the research, permission to 
conduct research was requested from the WCED, MSED Office and Schools; informed consent from LO educators and consent from the parents of Grade 12 learners was obtained. It should be noted that most research projects conform to widely accepted principles such as obtaining informed consent, ensuring voluntary participation and preserving confidentiality and privacy. The WCED and the MSED offices granted permission to conduct research in the schools. All participants received a formal letter of consent requesting to participate in the research. The letter provided information about the nature of the study and the conditions for participation. It also included an attached reply slip which required signatures as consent from both the $\mathrm{LO}$ educators and the relevant principals of the schools represented. Parental consent for minors was required and obtained from Grade 12 LO learners.

\section{Results}

The results of the data presented below reflect the views and perceptions of the participants, including the documents studied, as these relate to the way in which Parliament promotes active citizenship and how these views feature in the curriculum.

\section{Questionnaires}

The questionnaires generated mainly quantitative data through the crystallisation approach, using different methods of gathering data. The research instruments included semistructured focus group interviews and questionnaires. The questionnaire response rate was generally good for learners (61\%) and educators (67\%). The purpose of the questionnaire was to determine: (1) the level of knowledge about Parliament, (2) the extent to which participants were exposed to aspects relating to Parliament and (3) to what the extent of participation in the processes of Parliament.

\section{Learners' responses to the questionnaires}

Learners are generally uninformed about Parliament. For example, $62 \%$ did not know the number of houses of Parliament and $70 \%$ did not know how to participate in Parliament. In addition, $67 \%$ did not know who makes the laws in the country. Fifty per cent of the learners were never informed about the structures and functions of Parliament and $50 \%$ indicated that they were informed to a certain extent mainly through the media. Eighty-two per cent of the learners noted that they had never visited Parliament. In relation to the way in which Parliament features in the LO curriculum, $68 \%$ indicated that the $\mathrm{LO}$ curriculum does not teach them about Parliament. However, the majority of the learners $(96 \%)$ knew that 18 is the voting age.

\section{Educators' responses to the questionnaires}

Educators demonstrated basic knowledge about Parliament. Seventy-five per cent knew there is a difference between Parliament and Government, and 75\% knew Parliament makes laws. However, none of the educators (100\%) had visited Parliament prior to the study. The majority of the educators indicated that they were informed about Parliament through the media. Seventy-five per cent of the educators had an idea of ways to participate in Parliament but had never actively participated themselves; for example, they had never made a submission to Parliament or attended a public hearing. In relation to the way in which Parliament is featured in the LO curriculum, the majority of educators stated that the curriculum provides content about Parliament.

\section{Focus group interviews}

Grade 12 learners had limited knowledge about Parliament and did not know ways to participate and how to get involved in parliamentary processes:

'The only thing I know about Parliament is what I see on the news, with like Jacob Zuma and all [sic].' (School B, Learner 13, Grade 12)

'I think the function of Parliament is to acknowledge people of what is going on in the country and try to make it better, like the housing, education, schooling system, water, all of these problems, to solve this problems for the community or the country [sic].' (School D, Learner 38, Grade 12)

Educators had very limited understanding of Parliament and how to participate in parliamentary processes. Educators are aware that they can participate but had never participated before. However, they were more knowledgeable about participation at local government level:

'I think it starts in your community where you have got different wards and if there's a local ward and there's something affecting your local area and I think from there you can have input and I think from there it goes up [sic].' (School C, Educator C1, female)

With regard to the difference between Parliament and Government, educators understood that there is a difference. However, they do not understand the different roles and functions of each arm of State:

'Just in terms of Parliament making the laws, it's actually the Legislature that implements them isn't it? From here it goes up to Pretoria, that's how they make sure that the laws that are made here are implemented [sic].' (School E, Educator E1, female)

\section{Document study}

Various documents were studied relating to Parliament and the curriculum. The documents revealed that Parliament has a range of public participation mechanisms in place that promote active citizenship. The establishment of civic education and outreach programmes in Parliament suggest that, at the onset of a new democratic Parliament, the aim was to ensure that the public has a voice by influencing decision-making through political representatives in Parliament. This information was expressed as follows: Parliament provides access, as well as civic education and outreach programmes where needed, to 
build the relationship between Parliament and the people (Parliament of RSA 2006:113).

Parliament, as a participatory institution, has developed numerous programmes and projects to educate citizens about its role and processes and has undertaken initiatives to bring Parliament closer to citizens. The following statement emphasises the significance of public participation:

The participation of the public in the processes of Parliament, their access to the institution and its members, and information provided to the public remain a vital focus of Parliament. (Parliament of RSA 2012:13)

Since 1994, it has become possible for all citizens to become involved in Parliament through various public participation activities including public hearings, outreach programmes, radio programmes and broadcasts, television broadcasts, publications, newsletters, promotional material and the website. In addition, Parliament's sectoral programmes for public participation include the People's Assembly, Taking Parliament to the People, the Women's Parliament and the Youth Parliament (Parliament of RSA 2012).

Furthermore, the Public Education Office in Parliament has initiated the development of a parliamentary curriculum that can be useful for educators to use as resources when teaching content relating to active citizenship and Parliament. The publication, Understanding Parliament - A Teacher's Guide (Parliament of RSA 2011b), discusses various topics including democracy, nation building, the Constitution, the three arms of State, law-making and committees, amongst others.

The Grade 11 Life Orientation curriculum includes content about democratic participation in life, democratic participation and democratic structures. This suggests that educators may choose any democratic structure to teach the content and Parliament may not be the democratic structure of choice for the teacher. However, the LO curriculum provides limited information about democratic structures such as Parliament, which is one of the highest institutions of the country with democratic or participatory mechanisms in place (Arendse 2014). This may be the reason for the gap in the curriculum relating to active citizenship and related concepts such as democracy, human rights, citizenship, inclusivity and public participation.

In summary, the document study reveals that there have been many initiatives by Parliament and the Department of Education to promote active citizenship. However, there seems to be a mismatch with the implementation of such initiatives as much more is required to inform, educate and empower citizens to be able to participate and make meaningful contributions in democratic processes such as law-making and oversight. This is evident from the lack of knowledge and understanding amongst teachers to deliver knowledge about the role of Parliament effectively.

\section{Implications and recommendations}

This article explored the extent to which Parliament promotes active citizenship in relation to the LO curriculum. The results demonstrate that Grade 12 learners were not aware of how Parliament functions, which could be the cause of apathy towards Parliament. Furthermore, they were not aware that the public can influence decisionmaking in Parliament. Grade 12 learners were also not aware that Parliament is the national law-making body. This was evident because they had not been exposed to Parliament in any way. For example, they had never visited Parliament, they were not informed about Parliament, they did not know how to participate in the processes and activities of Parliament, and the LO curriculum does not provide adequate content to equip educators to teach about the role and work of Parliament.

However, it is worth noting that Parliament as a key participatory institution is mandated by the Constitution to facilitate public access and involvement in its processes in order to promote public participation and active citizenship (Constitution of RSA 1996). This mandate compels Parliament to ensure that members of the public are informed and equipped to participate in the processes of the institution. Citizens need to be equipped to manage their lives in the maze-like cultural and political environments in which they find themselves. By acquiring an education and developing skills, citizens young and old would be enhancing their economic competitiveness. Every citizen can do something useful for the development of their country and to live in better conditions (Shakaia 2016).

The study therefore suggests that active citizenship should be taught in school, including teaching about Parliament as it relates to active citizenship. Teaching active citizenry in schools is necessary as it empowers citizens from a young age to be able to make meaningful contributions to society and thus become responsible and active citizens. The study highlights that learners have not been prepared effectively to participate in democratic processes and structures. This finding is thus inconsistent with the intentions expressed in the national curriculum to equip learners with the knowledge, skills and values to become responsible and active citizens (DBE 2011b).

In addition, educators lack substantial knowledge and understanding about Parliament. The lack of understanding of roles of arms of State is an indicator either of apathy towards political processes or and they are just not well informed about democratic processes. Educators in this study had never participated in any process or activity of Parliament.

The study therefore suggests that learners have not been well informed about Parliament, be it through the curriculum or parliamentary educational programmes and initiatives. The curriculum does not teach learners about Parliament as it merely focuses on democratic structures in general. 
It is quite clear that there is a lack of knowledge and understanding about Parliament amongst learners and educators at school level. Evidently, there has been limited exposure to Parliament, yet educating members of the public about the processes of Parliament is a prerequisite for meaningful public participation (Parliament of RSA 2007).

The findings indicate that the impact of existing parliamentary education programmes may not necessarily increase participation in participatory institutions such as Parliament. Reaching many citizens is one thing; however, the extent to which communities are able to utilise the information to participate optimally in democratic processes is debatable. Information does not necessarily lead to active citizenship because citizens should first believe that they have the power either as an individual or in a group to make a difference in their community (Liberman, Posner \& Tsai 2014). Conversely, the parliamentary curriculum thus presents opportunities to learn about democracy, responsible citizenship, public participation and the structure, roles and functions of Parliament (Parliament of RSA 2011a).

The LO curriculum neither provides adequate content specifically about Parliament nor does restricts information about participation in one institution such as Parliament; however, it provides some content on democratic structures through public participation activities (DBE 2011a). It is therefore the schools' prerogative to select a democratic structure for teaching and learning, hence placing a huge responsibility on Parliament to educate the public about its processes. The primary challenges pertaining to effective public participation range from lack of sufficient information and lack of educational materials that may be regarded as leading factors to a lack of strong civil society interest and participation in democratic processes (Scott 2009).

Parliament has, indeed, since 1994 initiated programmes to promote public participation in its processes and activities. One of Parliament's strategic objectives focuses on promoting public participation in its legislative processes (Parliament of RSA 2013). Furthermore, there are existing public education programmes in place such as public education workshops, publications, electronic-based media and Parliament's curriculum (Parliament of RSA 2012).

These programmes encourage the public to participate actively in and influence decision-making in democratic structures such as Parliament. Many authors agree that education is a prerequisite for active and meaningful participation in democratic processes (Cecchini 2003; European Commission 2007; Honohan 2005; Hooper 2013; Houtzager \& Acharya 2010; Kisby \& Sloam 2012; McKenzie 1993; Meyer 1995; Nelson \& Kerr 2005; UNESCO 1998, 2005).

The LO curriculum content could be enhanced through educational partnerships with democratic structures such as Parliament. Learners from Grades R to 12, especially from senior phase, and educators would benefit from extensive exposure to information and education relating to democratic processes within a structure like Parliament.

\section{Conclusion}

In light of the findings suggesting that there is a lack of understanding and knowledge about Parliament, it is imperative to increase the level of awareness and education about Parliament as a key participatory institution. Parliament should continue developing active citizenship curricula that could be made available as a resource for formal, informal and non-formal education programmes. There should be an attempt by Parliament to become more visible and accessible to the public by integrating their programmes across the various sectors, including all spheres of government and organs of State. Furthermore, the LO curriculum could explore enhancing the citizenship education component with extensive information on the work of Parliament and explore various ways to increase access to information on democratic processes.

The focus of one of the strategic objectives of Parliament's is on strengthening public participation in its processes and activities, including law-making and oversight. As a key participatory institution that plays a vital role in promoting active citizenship in South Africa, Parliament and the Department of Education are thus obliged to ensure that citizens should be optimally informed, educated and empowered to be able to make meaningful contributions to democratic processes such as the law-making processes.

The challenge thus remains that public education programmes and initiatives at Parliament require much work and development in order to enhance active citizenship programmes. In addition, democratic structures should find strategic ways to inform and educate members of the public optimally. Adequate funding should therefore be made available to educate and inform the South African population.

It is worth noting that a healthy democracy requires each citizen to know his or her rights and enables them to exercise their rights in a democratic society by influencing political decision-making. Education for citizenship should be regarded as being central to active citizenship. It should thus become a tool for educating children from an early age to become informed citizens in order to be able to participate actively in and contribute meaningfully to society (UNESCO 1998). The national curriculum could benefit from educating children from an early age about active citizenship by strengthening the existing infusion of citizenship education.

\section{Acknowledgements}

The authors thank the Western Cape Education Department for granting permission to conduct the case study by Agnetha Arendse. They also thank the Metro South Education District and the participating schools (including 
principals, educators, learners and parents) that co-operated to make this study possible.

\section{Competing interests}

The authors have declared that no competing interests exist.

\section{Authors' contributions}

A.A. conducted the research and contributed mainly to the literature and methodology. J.S. supervised the research, proofread and contributed mainly to the discussion and conclusion. Both authors conceptualised the study.

\section{Funding information}

The University of the Western Cape will fund this article.

\section{Data availability statement}

Data sharing is not applicable to this article as no new data were created or analysed in this study.

\section{Disclaimer}

The views and opinions expressed in this article are those of the authors and do not necessarily reflect the official policy or position of any affiliated agency of the authors

\section{References}

Arendse, A., 2014, 'The grade 11 life orientation curriculum: Towards preparation for active citizenship in a democratic South Africa', Doctoral thesis, University of the Western Cape, Bellville.

Babbie, E. \& Mouton, J., 2001, The practice of social research, Oxford University Press, Cape Town.

Baxter, P. \& Jack, S., 2008, 'Qualitative case study. Methodology: Study design and implementation for novice researchers', The Qualitative Report 13(4), 544-549.

Calland, R. (ed.), 1999, The first 5 years: A review of South Africa's democratic parliament, IDASA, Cape Town.

Cecchini, M., 2003, Active citizenship: Adult learning and active citizenship and lifelong learning and active citizenship, EAFA Conference, Council of Europe, Cyprus.

Constitution of the Republic of South Africa (RSA), 1996, Constitution of the Republic of South Africa, Government Printers, Cape Town.

Coolican, H., 1999, Research methods and statistics in psychology, 3rd edn., Hodder and Stoughton, Great Britain.

Department of Basic Education (DBE), 2010, Curriculum and assessment policy statements, CAPS, life orientation grades 7-9, Final Draft, Government Printers, Pretoria.

Department of Basic Education (DBE), 2011a, Curriculum and assessment policy statements, CAPS, Grade R-3. Life skills, Government Printers, Pretoria.

Department of Basic Education (DBE), 2011b, Curriculum and assessment policy statements, CAPS, grades 10-12. Life Orientation, Government Printers, Pretoria.

Department of Education (DoE), 1997, Curriculum 2005, Department of Education, Pretoria.

De Villiers, S., 2001, A people's government. The people's voice. A review of public participation in the law and policy-making in South Africa, Parliamentary Support Programme, Cape Town.

European Commission, 2007, Study on active citizenship education, European Commission, Europe, Brussels.

European Commission, 2012, Citizenship education in Europe, Education, Audiovisual and Culture Executive Agency, Brussels.

Ewert, G.D., 1991, 'Habermas and education: A comprehensive overview of the influence of Habermas in educational literature', Review of Educational Research 6(3), 345-378. https://doi.org/10.3102/00346543061003345

Freire, P., 1971, Pedagogy of the oppressed, The Continuum Publishing Corporation, New York.

Gall, M.D., Borg, W.R. \& Gall, J.P., 1996, Educational research: An introduction, Longman, New York.
Gillespie, A., 2002, Skills-based health education to prevent HIV/AIDS: The case against integration, UNICEF, viewed 20 June 2012, from http://www.inicef.org/ programme/lifeskills/priorities/placement/html.

Harmon, M., 1975, 'Paulo Freire: Implications for a theory of pedagogy', Doctoral dissertation, University of Massachusetts, USA

Henning, E., Van Rensburg, W. \& Smit, B., 2004, Find your way in qualitative research, Van Schaik, Pretoria.

Honohan, I., 2005, 'Active citizenship in contemporary democracy', in C. Harris (ed.), Engaging citizens: Report of the Democracy Commission, TASC/New Island Press, Dublin.

Hooper, S., 2013, 'Small spaces for meaningful participation in democratic life? A community's perspectives on their participation in an early education and care program', Doctoral thesis, University of Toronto, Toronto.

Houtzager, P.P. \& Acharya, A.K., 2010, Associations, active citizenship, and the quality of democracy in Brazil and Mexico, Springer, New York. Published online.

Institute for Democracy Association in South Africa (IDASA) - An African Democracy Institute, 2012, Public participation, viewed 30 December 2012, from http:// advocay.org.za/index.asp?

Keet, A., Masuku, N., Meyers, A., Farisani, M., Carrim, N. \& Govender, S., 2001, The national curriculum statement and the promotion and protection of human rights, values and inclusivity, Guidelines document, Final draft, Human Rights and Inclusivity Working Group, Pretoria.

Kisby, B. \& Sloam, J., 2012, 'Citizenship, democracy and education in the UK: Towards a common framework for citizenship lessons in the four home nations', Oxford Journals 65, 68-89. https://doi.org/10.1093/pa/gsr047

Kuye, J.O., 2007, 'The role of public administration in leadership and governance: A review of civics, citizenship and political education', Journal of Public Administration 42, 597-613.

Liberman, E.S., Posner, D.M. \& Tsai, L.L., 2014, 'Does information lead to more active citizenship? Evidence from an education intervention in rural Kenya', World Development 29, 69-83. https://doi.org/10.1016/j.worlddev.2014. 03.014

McCloskey, S., 2017, 'Brexit, Trump and development education. View point', Policy \& Practice: A Development Education Review 24, 159-167.

McCowan, T., 2006, 'Approaching the political in citizenship education: The perspectives of Paulo Freire and Bernard Crick', Educate - The London Journal of Doctoral Research in Education 6(1), 57-70.

McKenzie, H., 1993, Citizenship education in Canada, viewed 28 May 2011, from http:// dsp-psd.pwgsc.gcc.ca/collection-R/LoPBd/BP/bp226-e.htm\#introduction,txt.

Meyer, B.P., 1995, Introduction - A culture of democracy: A challenge for schools, United Nations Educational, Scientific and Cultural Organisation, UNESCO, Paris.

National Development Plan 2030 (NDP), 2012, Our future - Make it work, Shereno Printers, Boksburg.

Nelson, J. \& Kerr, D., 2005, Active citizenship: Definitions, goals and practices, National Foundation for Educational Research, London.

Parliament of the Republic of South Africa (RSA), 2006, Parliament since 1994 Achievements and challenges, Parliament Printers, Cape Town.

Parliament of the Republic of South Africa (RSA), 2010, Public participation, viewed 09 October 2011, from http://www.parliament.gov.za.

Parliament of the Republic of South Africa, 2011a, Public education office business plan 2012/2013, Parliament of the Republic of South Africa, Cape Town.

Parliament of the Republic of South Africa (RSA), 2011b, Understanding parliament: A teacher's guide, Oxford University Press, Cape Town.

Parliament of the Republic of South Africa (RSA), 2012, Parliament's annual performance plan: 2013/2014 - 2015/2016, Parliament of the Republic of South Africa, Cape Town.

Parliament of the Republic of South Africa (RSA), 2013, Strategic plan for parliament: 2009-2014, Parliament of South Africa, Cape Town.

Parliament of the Republic of South Africa (RSA), Parliamentary Communication Services (PCS), 2007, From public affairs to the Parliamentary Communication Services, Unpublished, Cape Town.

Rooth, E. \& Schlebusch, A., 2000, Report on pilot grade 7 training in the Western Cape, Cape Town, Unpublished report, Western Cape Education Department.

Schostak, J.F., 2002, Understanding, designing and conducting qualitative research in education. Framing the project, Open University Press, London.

Scott, R., 2009, An analysis of public participation in the South African legislative sector, University of Stellenbosch, Stellenbosch.

Sen, A., 1999, 'Democracy as a universal value', Journal of Democracy 10, 3-17. https://doi.org/10.1353/jod.1999.0055

Shakaia, N., 2016, The importance of citizen's participation, Citizen Journalist-Citizens' \& Participation.

Smith, J. \& Arendse, A., 2016, 'South African curriculum reform: Education for active citizenship', Bulgarian Comparative Education Society Conference Book 14(1), 65-72. https://doi.org/10.1057/978-1-137-54443-8_1

Strydom, H. \& Delport, C.S., 2005, 'Information collection: Document study and secondary analysis', in A.S. De Vos, H. Strydom, C.B. Fouche \& C.S. Delport (eds.), Research at grass roots: For the social sciences and human service professions, pp. 314-326, Van Schaik, Pretoria. 
Terre Blanche, M. \& Durrheim, K., 2006, 'Histories of the present: Social science research in context', in M. Terre Blanche, K. Durrheim \& D. Painter (eds.), Research in practice: in context', in M. Terre Blanche, K. Durrheim \& D. Painter (eds.), Research in practice:
Methods for social sciences, vol. 2, pp. 1-17, University of Cape Town, Cape Town.

Torres, C.A. \& Teodoro, A., 2007, Critique and Utopia: New developments in the sociology of education in the twenty first century, Rowan Littlefield Publishers, New York.

UNESCO, 1998, Citizenship education for the 21st century, viewed 02 October 2011 from http://www.unescobkk.org.
UNESCO, 2005, Education for citizenship - Learning to live together with respect for the other that is the essential challenge of education for citizenship,
United Nations Educational, Scientific and Cultural Organisation, UNESCO, Brussels.

Vaughn, R., 2008, Conceptual framework. Presentation by Professor Roger Vaughn, Bournemouth University, London.

Wright, E.O., 2007, 'The tasks of emancipatory social science', in E.O. Wright (ed.), Envisioning real Utopias, pp. 11-29, Verso, London. 